\title{
Effect of Dextran and Ammonium Sulphate on the Reaction Catalysed by a Glucosyltransferase Complex from Streptococcus mutans
}

\author{
By B. MARY NEWMAN, $†$ PAMELA WHITE, \\ SUDESH B. MOHAN AND J. A. COLE* \\ Department of Biochemistry, University of Birmingham, Birmingham B15 2TT
}

(Received 12 April 1979; revised 25 January 1980)

\begin{abstract}
The highly aggregated proteins precipitated by $\left(\mathrm{NH}_{4}\right)_{2} \mathrm{SO}_{4}$ from the culture fluid of three strains of Streptococcus mutans gradually released less aggregated glucosyltransferase activities - dextransucrase and mutansucrase - which catalysed the synthesis of watersoluble and insoluble glucans from sucrose. Mutansucrase was eluted from a column of Sepharose $6 \mathrm{~B}$ before dextransucrase. This activity was lost during subsequent dialysis and gel filtration, but there was a corresponding increase in dextransucrase activity which catalysed the formation of soluble glucan when incubated with sucrose alone, and insoluble glucan when incubated with sucrose and $1.55 \mathrm{M}-\left(\mathrm{NH}_{4}\right)_{2} \mathrm{SO}_{4}$. Relative rates of synthesis of soluble and insoluble glucan in the presence of $1.55 \mathrm{M}-\left(\mathrm{NH}_{4}\right)_{2} \mathrm{SO}_{4}$ were dependent upon the enzyme concentration: high concentrations favoured insoluble glucan synthesis. Insoluble glucans synthesized by mutansucrase or by dextransucrase in the presence of $1.55 \mathrm{M}$ - $\left(\mathrm{NH}_{4}\right)_{2} \mathrm{SO}_{4}$ were more sensitive to hydrolysis by mutanase than by dextranase, but soluble glucans were more extensively hydrolysed by dextranase than by mutanase. Partially purified dextransucrase sedimented through glycerol density gradients as a single symmetrical peak with an apparent molecular weight in the range 100000 to 110000 . In the presence of $1.55 \mathrm{M}-\left(\mathrm{NH}_{4}\right)_{2} \mathrm{SO}_{4}$, part of the activity sedimented rapidly as a high molecular weight aggregate. The results strongly suggest that soluble and insoluble glucans are synthesized by interconvertible forms of the same glucosyltransferase. The aggregated form, mutansucrase, preferentially catalyses $(1 \rightarrow 3)-\alpha$ bond formation but dissociates during gel filtration to the dextransucrase form which catalyses $(1 \rightarrow 6)-\alpha$ bond formation.
\end{abstract}

\section{INTRODUCTION}

Streptococcus mutans is a major causative organism of human dental caries (de Stoppelaar et al., 1968; Sherp, 1971) and a major determinant of a strain's pathogenicity is its ability to synthesize an insoluble glucan from sucrose (Gibbons \& Nygaard, 1968; Koga \& Inoue, 1978). This insoluble glucan, called mutan, is a sticky polymer which promotes the retention of bacteria to, and inhibits the diffusion of acidic fermentation products from, the tooth surface.

Enzymes which catalyse glucan synthesis are collectively known as glucosyltransferases. Extracellular proteins from cultures of $S$. mutans catalyse the synthesis of both watersoluble and insoluble glucans from sucrose. The major type of glycosidic bond in the soluble glucan is $(1 \rightarrow 6)-\alpha$ so, although other bond types are invariably present, the glucosyl-

† Present address: Faculty of Health Sciences, University of Ilorin, P.M.B. 1515, Ilorin, Nigeria. 
transferase involved in its synthesis is called dextransucrase (McCabe \& Smith, 1973). In contrast, the glucosyl residues of mutan are linked predominantly by $(1 \rightarrow 3)-\alpha$ bonds with a minority of $(1 \rightarrow 6)-\alpha$ and other linkages (Lewicki et al., 1971; Baird et al., 1973; Ebisu et al., 1974). The name dextransucrase has previously been used by some authors to refer to glucosyltransferases which catalyse the synthesis of both soluble and insoluble glucans and it has thereby been implied that a single protein is involved in both processes (McCabe \& Smith, 1973; Robyt \& Corrigan, 1977). An alternative possibility is that mutan is synthesized by two or more proteins, including a dextransucrase which inserts $(1 \rightarrow 6)-\alpha-$ linked glucosyl residues into the growing polysaccharide and a second enzyme that catalyses the formation of $(1 \rightarrow 3)-\alpha$ linkages (Guggenheim \& Newbrun, 1969; Cole, 1977). As the number of proteins required for mutan synthesis is still unknown, in this paper this type of glucosyltransferase activity will be referred to as mutansucrase.

Attempts to purify mutansucrase have yielded conflicting results, especially with respect to the molecular weight of the proteins (Fukui et al., 1974; Schachtele et al., 1976) and their ability to use preformed dextran as a primer or precursor of mutan synthesis (compare Germaine et al., 1977, with Robyt \& Corrigan, 1977). Highly purified samples of glucosyltransferases have been prepared in several laboratories, but samples which enter the gel matrix during polyacrylamide gel electrophoresis invariably catalyse the synthesis of soluble glucans in which $(1 \rightarrow 6)-\alpha$ glycosidic bonds predominate (Fukui et al., 1974; Kuramitsu, 1975). We have previously reported that little mutansucrase activity was detected in proteins which redissolved in $0.1 \mathrm{M}$-acetate buffer after precipitation from culture filtrates by $70 \%$ saturated $\left(\mathrm{NH}_{4}\right)_{2} \mathrm{SO}_{4}$ (Mohan et al., 1979). Mutan synthesis was stimulated, however, when these redissolved proteins were incubated with sucrose and an equal volume of the $70 \%$ saturated $\left(\mathrm{NH}_{4}\right)_{2} \mathrm{SO}_{4}$ supernatant fraction, or with $\left(\mathrm{NH}_{4}\right)_{2} \mathrm{SO}_{4}$ itself. This final concentration of $\left(\mathrm{NH}_{4}\right)_{2} \mathrm{SO}_{4}(1.55 \mathrm{M}$ or $35 \%$ saturation) is sufficient to aggregate and precipitate some proteins from solution, so it was suggested that mutansucrase and dextransucrase activities might be due to interconvertible forms of the same enzyme. The aims of the present work were to examine the possible release of dextransucrase activity from a mutansucrase aggregate, and whether dextransucrase can recombine with other protein fractions or reaggregate in the presence of $\left(\mathrm{NH}_{4}\right)_{2} \mathrm{SO}_{4}$ and catalyse mutan synthesis.

Ellwood et al. (1976) have documented the changes in the rates of glucosyltransferase synthesis that have occurred during the maintenance of clinical isolates of $S$. mutans on conventional laboratory media. The relevance to the disease process of many of the earlier glucosyltransferase studies is therefore in doubt. To avoid this criticism, many of our experiments with the well-characterized laboratory strain, C67-1, have been repeated with a fresh clinical isolate, strain 3209.

\section{METHODS}

Organisms, growth conditions and concentration of extracellular proteins. Streptococcus mutans strain 3209 was isolated in December 1977 by Miss D. A. Sidaway from the dentine of a carious fissure in a permanent tooth of a patient in the Birmingham Dental Hospital. It was maintained on horse blood agar and subcultured every $14 \mathrm{~d}$ by transferring bacteria from an area of confluent growth on to a fresh blood agar plate. The serotype, $c$, was determined by Dr R. R. B. Russell, The Royal College of Surgeons of England, Downe, Kent. Strains C67-1 and C67-25 were obtained as freeze-dried cultures from Dr J. M. Hardie, The London Hospital Medical College, Turner Street, London E1 2AD.

Bacteria were grown in continuous culture with excess glucose at a dilution rate of $0 \cdot 12 \pm 0 \cdot 01 \mathrm{~h}^{-1}$ and pH $6 \cdot 55 \pm 0 \cdot 1$, as described by Wenham et al. (1979). Extracellular proteins from the spent growth medium were concentrated by precipitation with $70 \%$ saturated $\left(\mathrm{NH}_{4}\right)_{2} \mathrm{SO}_{4}$ as described by Mohan et al. (1979). The pellet was homogenized with $10 \mathrm{ml} 0 \cdot 1 \mathrm{M}$-sodium acetate/acetic acid buffer, $\mathrm{pH} 6.0$ ('acetate buffer') for $10 \mathrm{~min}$ at $4{ }^{\circ} \mathrm{C}$ and immediately collected by centrifugation for $10 \mathrm{~min}$ at $30000 \mathrm{~g}$. The pellet was immediately extracted three more times by homogenization with acetate buffer and centrifugation after $30 \mathrm{~min}$ at $4{ }^{\circ} \mathrm{C}$. The final pellet was homogenized with 6 to $10 \mathrm{ml}$ acetate buffer. 
Enzyme assays. To assay glucosyl- and fructosyltransferase activities, $1 \mathrm{ml}$ of culture supernatant, or $0.1 \mathrm{ml}$ of concentrated protein solution or column fraction, was incubated for 0.5 to $2 \mathrm{~h}$ at $37^{\circ} \mathrm{C}$ with 0.5 or $1.4 \mathrm{ml}$ acetate buffer and $0.5 \mathrm{ml} 0.29 \mathrm{M}$-sucrose, with or without $60 \mu \mathrm{g}$ primer dextran $\mathrm{ml}^{-1}$ (mol. wt range 60000 to $90000 ; \mathrm{BDH})$. In some experiments, insoluble glucans were collected by centrifugation after addition of $0.2 \mathrm{ml} 10 \%(\mathrm{w} / \mathrm{v})$ trichloroacetic acid to stop the reaction. The pellet was resuspended in water and recollected by centrifugation and the washings were combined with the original supernatant fluid. Methanol at room temperature was then added to $80 \%(\mathrm{v} / \mathrm{v})$ and tubes were cooled at $4{ }^{\circ} \mathrm{C}$ for at least $50 \mathrm{~min}$ to precipitate water-soluble polysaccharides. The quantities of polysaccharide and ketohexose formed were then determined as described by Mohan et al. (1979).

The phenol-sulphuric acid reagent used to assay glucans also reacts with fructans which may be synthesized from sucrose (Dubois et al., 1956). For this reason it was necessary to determine the relative activities of glucosyl- and fructosyltransferases in each type of experiment, as described by Wenham et al. (1979). Furthermore, the dextransucrase activity of a serotype $c$ strain of $S$. mutans was almost entirely dextrandependent (Wenham et al., 1979), so without appropriate controls it is impossible to conclude whether $\left(\mathrm{NH}_{4}\right)_{2} \mathrm{SO}_{4}$ or dextran are altering rates of synthesis of soluble glucan, insoluble glucan or fructan. Tubes which were not incubated, together with those from which sucrose or enzyme were omitted, were included as controls in each set of assays. The quantities of ketohexose or total polysaccharide in these tubes were subtracted from corresponding quantities in assay tubes before the sucrose-dependent rates of fructan and glucan synthesis were calculated (Wenham et al., 1979; Mohan et al., 1979). These corrections were negligible for assays with glucosyltransferase which had been filtered through Sepharose 6B and were, at most, $20 \%$ of the quantity of glucan or fructan formed when crude enzyme preparations were incubated with sucrose. Wenham (1979) has documented the validity of these procedures.

Gel filtration. A column containing Sepharose 6 B (60 to $65 \mathrm{~cm}$ long; $2 \cdot 3 \mathrm{~cm}$ diam.) was equilibrated with $2 \mathrm{M}-\mathrm{NaCl}$ in acetate buffer. Enzyme samples were concentrated by dialysis against polyethylene glycol 6000 , then dialysed against several changes of $2 \mathrm{M}-\mathrm{NaCl}$ in acetate buffer at $4{ }^{\circ} \mathrm{C}$, and applied to and eluted from the Sepharose column in $2 \mathrm{M}-\mathrm{NaCl}$ in acetate buffer at 18 to $20^{\circ} \mathrm{C}$. The flow rate was $18 \mathrm{ml} \mathrm{h}-1$ and approximately $5 \mathrm{ml}$ fractions were collected.

Sedimentation of glucosyltransferase through glycerol gradients. The pooled fractions containing dextransucrase activity from the Sepharose 6B column were concentrated by dialysis against polyethylene glycol and dialysed against acetate buffer in the presence or absence of $1.55 \mathrm{M}-\left(\mathrm{NH}_{4}\right)_{2} \mathrm{SO}_{4}$. Samples $(0 \cdot 3 \mathrm{ml})$ were loaded on to $12.6 \mathrm{ml}$ linear 10 to $30 \%(\mathrm{v} / \mathrm{v})$ glycerol gradients which were centrifuged and fractionated as described by Coleman et al. (1978). Fumarate hydratase $\left(s_{20, w}=9 \mathrm{~S}\right.$; mol. wt 194000) and catalase $\left(s_{20, w}=\right.$ $11.3 \mathrm{~S}$; mol. wt 250000 ) were used as molecular weight markers in some gradients.

Sucrose was not used to prepare density gradients because it is a substrate for glucosyltransferase and is converted to products which might substantially alter both the shape and the molecular weight of the enzyme. Glycerol was not an ideal substitute because at $30 \%(\mathrm{v} / \mathrm{v})$ it inhibited the rate of glucan synthesis by $30 \%$. This inhibition was completely reversible by dialysis, so it is unlikely that glycerol promotes a major alteration in the structure of glucosyltransferase.

Polyacrylamide gel electrophoresis. Proteins were separated by electrophoresis in the presence of sodium dodecyl sulphate (SDS), as described by Laemmli (1970), with a $5.5 \%(\mathrm{w} / \mathrm{v}$ ) stacking gel and a $9 \%$ resolving gel. Concentrated samples were diluted to 0.1 to $1.0 \mathrm{mg}$ protein $\mathrm{ml}^{-1}$ with $20 \%(\mathrm{v} / \mathrm{v})$ glycerol, $10 \%(\mathrm{v} / \mathrm{v})$ mercaptoethanol and $6 \%(\mathrm{w} / \mathrm{v}) \mathrm{SDS}$ in $0 \cdot 12 \mathrm{~m}$-Tris/HCl, pH 6.8, and boiled for $5 \mathrm{~min}$. Bromophenol Blue [1 vol. of a $0.05 \%(\mathrm{w} / \mathrm{v})$ solution in water to 7 vol. of sample] was added and solutions containing 10 to $15 \mu \mathrm{g}$ sample protein or $50 \mu \mathrm{g}$ of the mixed marker proteins were applied to the gel. After electrophoresis, protein was stained with Coomassie Brilliant Blue R250, and gels were destained with $10 \%(\mathrm{v} / \mathrm{v})$ acetic acid. Alternatively, some gels were incubated for $48 \mathrm{~h}$ at $37{ }^{\circ} \mathrm{C}$ with acetate buffer containing $10 \%(\mathrm{w} / \mathrm{v})$ sucrose or raffinose, $1 \%(\mathrm{w} / \mathrm{v})$ Lubrol and $120 \mu \mathrm{g}$ dextran $\mathrm{ml}^{-1}$.

Proteins used as molecular weight markers were transferrin (78000), bovine serum albumin (69000), bovine glutamate dehydrogenase (53000), lactate dehydrogenase (36000) and egg white lysozyme (14300).

Chemicals and chemical analyses. Protein, total carbohydrate and ketohexose were determined as described by Mohan et al. (1979). The fructosyltransferase activity of the glucosyltransferase pool eluted from Sepharose $6 \mathrm{~B}$ was only 2 to $10 \%$ of the total rate of polysaccharide synthesis. Errors in soluble glucan determinations due to irreproducibility in the colour intensity contributed by fructans in the phenol-sulphuric acid assay were therefore extremely small. All assays were duplicated, and replicates rarely differed from the mean by as much as $2 \%$.

Samples of water-soluble and insoluble glucans were incubated with dextranase or mutanase and the susceptibility to hydrolysis of glycosidic bonds was determined from the increase in concentration of reducing sugar (Hodge \& Hofreiter, 1962). Both dextranase and mutanase released reducing equivalents during incubation in the absence of added glucan, so conditions optimal for detecting glucan hydrolysis were 
Table 1. Solubility of glucosyl- and fructosyltransferase activities in acetate buffer after precipitation by ammonium sulphate

Proteins precipitated from 3.71 of strain 3209 culture supernatant were resuspended four times in acetate buffer, and redissolved proteins were collected by centrifugation for $10 \mathrm{~min}$ at $30000 \mathrm{~g}$. Enzyme activities are expressed as $\mathrm{mg}$ glucose or fructose from sucrose incorporated into polysaccharide $\mathrm{h}^{-1} \mathrm{ml}^{-1}$.

\begin{tabular}{|c|c|c|c|c|c|c|c|}
\hline \multirow[b]{2}{*}{$\begin{array}{l}\text { Enzyme sample } \\
\text { (vol.) }\end{array}$} & \multirow[b]{2}{*}{$\begin{array}{l}\text { Protein } \\
\left(\mathrm{mg} \mathrm{ml}^{-1}\right)\end{array}$} & \multirow[b]{2}{*}{$\begin{array}{l}\text { Carbohydrate } \\
\left(\mathrm{mg} \mathrm{ml}^{-1}\right)\end{array}$} & \multirow[b]{2}{*}{$\begin{array}{l}\text { Dextran } \\
\text { in assay }\end{array}$} & \multirow[b]{2}{*}{$\begin{array}{l}\text { Fructosyl- } \\
\text { transferase } \\
\text { activity }\end{array}$} & \multicolumn{3}{|c|}{ Glucosyltransferase activity } \\
\hline & & & & & $\begin{array}{c}\begin{array}{c}\text { Soluble } \\
\text { glucan } \\
-\left(\mathrm{NH}_{4}\right)_{2} \mathrm{SO}_{4}\end{array}\end{array}$ & $\overbrace{-\underset{\left.\mathrm{NO}_{4}\right)_{2}}{\text { Insoluble }}}^{\mathrm{SO}_{4}}$ & 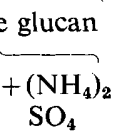 \\
\hline Extract $1(10 \mathrm{mI})$ & $5 \cdot 7$ & $17 \cdot 8$ & $\overline{-}$ & $\begin{array}{l}0.40 \\
0.25\end{array}$ & $\begin{array}{l}0 \cdot 16 \\
0 \cdot 44\end{array}$ & $\begin{array}{l}0.45 \\
0.72\end{array}$ & $\begin{array}{l}0.70 \\
-\end{array}$ \\
\hline Extract $2(13 \mathrm{ml})$ & $14 \cdot 6$ & $14 \cdot 7$ & $\overline{+}$ & $\begin{array}{l}5 \cdot 3 \\
4 \cdot 9\end{array}$ & $\begin{array}{l}5 \cdot 8 \\
9 \cdot 1\end{array}$ & $\begin{array}{l}0 \cdot 84 \\
0 \cdot 74\end{array}$ & $\begin{array}{l}6 \cdot 7 \\
--\end{array}$ \\
\hline Extract $3 \quad(8 \mathrm{ml})$ & $20 \cdot 0$ & $8 \cdot 8$ & $\bar{t}$ & $\begin{array}{l}11 \cdot 8 \\
11 \cdot 6\end{array}$ & $\begin{array}{l}35 \cdot 6 \\
39 \cdot 2\end{array}$ & $\begin{array}{l}3 \cdot 4 \\
4 \cdot 1\end{array}$ & $\begin{array}{c}20 \cdot 2 \\
-\end{array}$ \\
\hline Extract $4 \quad(7 \mathrm{ml})$ & $24 \cdot 3$ & $8 \cdot 0$ & $\begin{array}{l}- \\
+\end{array}$ & $\begin{array}{r}10 \cdot 3 \\
9 \cdot 5\end{array}$ & $\begin{array}{l}20 \cdot 0 \\
23 \cdot 5\end{array}$ & $\begin{array}{l}2 \cdot 0 \\
3 \cdot 9\end{array}$ & $\begin{array}{c}15 \cdot 5 \\
-\end{array}$ \\
\hline $\begin{array}{l}\text { Final pellet resusper } \\
\text { in acetate buffer }\end{array}$ & $\begin{array}{l}\text { d } 14 \cdot 5 \\
\text { nl) }\end{array}$ & $10 \cdot 3$ & $\overline{-}$ & $\begin{array}{l}7 \cdot 8 \\
7 \cdot 8\end{array}$ & $\begin{array}{l}1 \cdot 5 \\
3 \cdot 0\end{array}$ & $\begin{array}{l}13 \cdot 7 \\
13 \cdot 3\end{array}$ & $\begin{array}{c}12 \cdot 2 \\
-\end{array}$ \\
\hline
\end{tabular}

determined. Subsequently, a freshly prepared solution of dextranase or mutanase $\left(1 \cdot 0 \mathrm{mg} \mathrm{m}^{-1}\right)$ was incubated with polymer $\left(0.9\right.$ to $\left.2.0 \mathrm{mg} \mathrm{ml}^{-1}\right)$ for $2 \mathrm{~h}$ at $37^{\circ} \mathrm{C}$. After $2 \mathrm{~min}$ in a boiling water bath, 0.1 to $0.5 \mathrm{ml}$ samples were diluted to $1.0 \mathrm{ml}$ with distilled water, mixed with $1.0 \mathrm{ml} \mathrm{Cu}{ }^{2+}$ reagent, heated to $100{ }^{\circ} \mathrm{C}$ for $20 \mathrm{~min}$ and cooled. The arsenomolybdate reagent $(1.0 \mathrm{ml})$ was then added, followed by $7.0 \mathrm{ml}$ distilled water. The $A_{570}$ of the samples were compared with the $A_{570}$ produced by standard glucose solutions ( 0 to $100 \mu \mathrm{g}$ ).

The types of glycosidic linkage in glucan polymers were determined by methylation, methanolysis and gas-liquid chromatographic techniques described in detail by Baird et al. (1973). At least $96 \%$ of the bonds in the dextran sample were $(1 \rightarrow 6)-\alpha$ and $90 \%$ of the bonds in the insoluble glucan were $(1 \rightarrow 3)-\alpha$.

Raffinose, dextran and polyethylene glycol were obtained from $\mathrm{BDH}$, and Lubrol sample 12A9 was a gift from ICI. The standard $(1 \rightarrow 3)-\alpha$-glucan was purified from Peptobovus betulinus and was a gift from D. C. Ellwood.

\section{RESULTS}

\section{Sequential solubilization of extracellular proteins precipitated by ammonium sulphate}

Little enzyme activity redissolved during the initial extraction with acetate buffer of proteins precipitated from culture supernatant of strain 3209 by $70 \%$ saturated $\left(\mathrm{NH}_{4}\right)_{2} \mathrm{SO}_{4}$ (Table 1), but the trace of dextransucrase activity was stimulated by dextran. Most of the fructosyltransferase and dextransucrase activities redissolved during the third and fourth extractions, but $70 \%$ of the mutansucrase activity was recovered in the final insoluble pellet. None of these activities was greatly stimulated by dextran, but each sample was heavily contaminated with polysaccharide (Table 1). Virtually identical results were obtained when extracellular proteins from strain C67-1 were precipitated by $70 \%$ saturated $\left(\mathrm{NH}_{4}\right)_{2} \mathrm{SO}_{4}$.

Rates of insoluble glucan synthesis by the redissolved proteins were stimulated 6- to 8 -fold by $1.55 \mathrm{M}$ - $\left(\mathrm{NH}_{4}\right)_{2} \mathrm{SO}_{4}$, but mutan synthesis by the final pellet was slightly inhibited. The increased rate of insoluble glucan synthesis therefore appears to be due to an effect of $\left(\mathrm{NH}_{4}\right)_{2} \mathrm{SO}_{4}$ on dextransucrase activity rather than on mutansucrase. To test this suggestion convincingly, glucosyltransferase was first partially purified to separate it from the contaminant fructosyltransferase activity. 

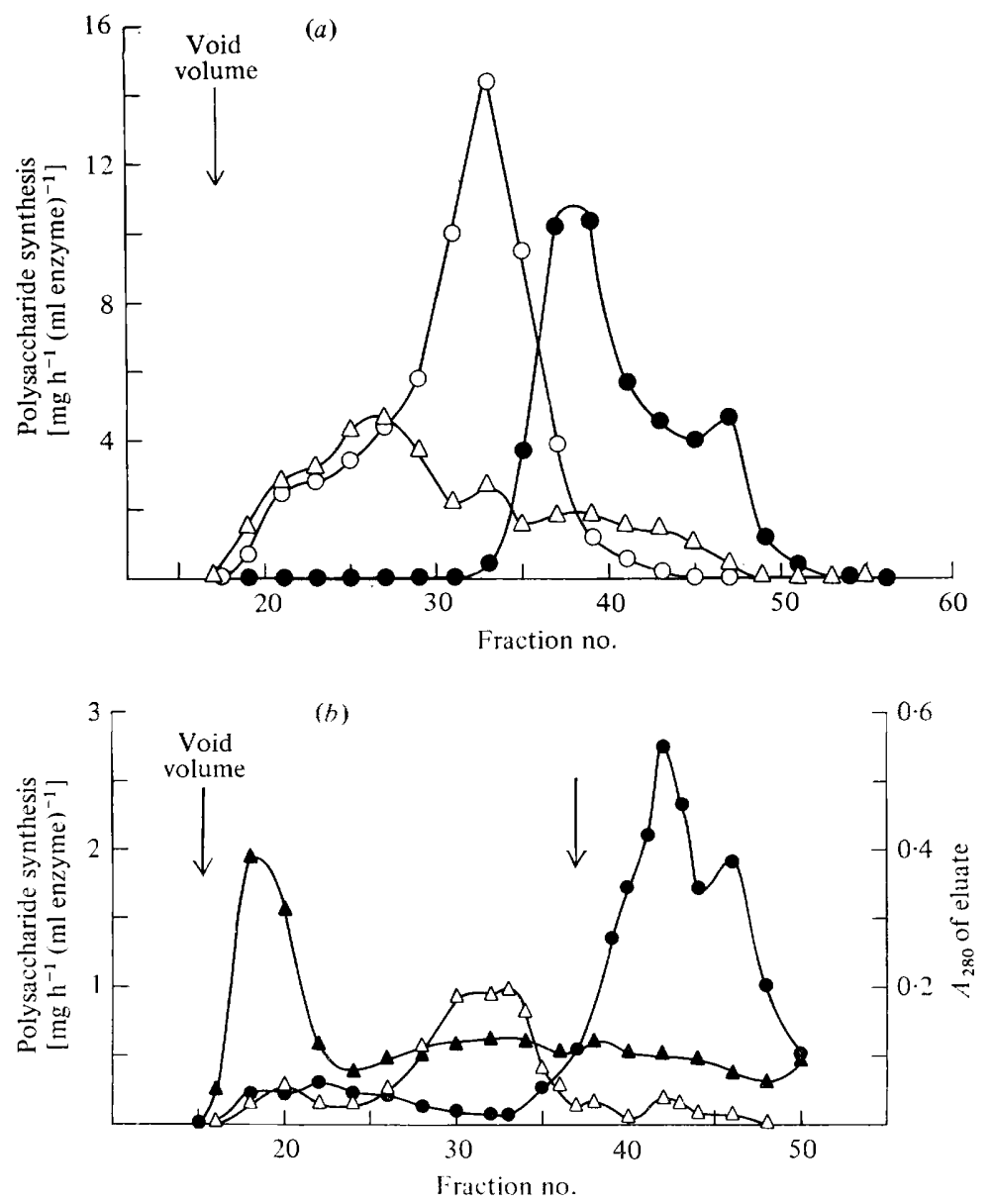

Fig. 1. Elution of various glucosyltransferase samples (strain 3209) from Sepharose 6B. The samples and the columns were equilibrated with $2.0 \mathrm{M}-\mathrm{NaCl}$ in $0.1 \mathrm{M}$-sodium acetate, pH 6.0 . Each sample ( 7 to $10 \mathrm{ml} ; 10$ to $20 \mathrm{mg}$ protein $\mathrm{ml}^{-1}$ ) was re-equilibrated with the column buffer and loaded on to the column. The flow rate was $18 \mathrm{ml} \mathrm{h}^{-1}$ and 4.8 to $5.0 \mathrm{ml}$ fractions were collected. The samples were (a) pooled proteins which redissolved in extracts 2, 3 and 4 from the initial $70 \%$ saturated $\left(\mathrm{NH}_{4}\right)_{2} \mathrm{SO}_{4}$ pellet (Table 1); (b) the mutansucrase pool (fractions 29 to 33 ) from $(a)$. $\bigcirc$, Mutansucrase activity [without $\left(\mathrm{NH}_{4}\right)_{2} \mathrm{SO}_{4}$ in the assay]; $O$, soluble glucan synthesis; $\triangle$, fructosyltransferase activity; $\boldsymbol{\Delta}, A_{280}$. The arrow in $(b)$ indicates the expected position for elution of mutansucrase activity.

\section{Elution of glucosyltransferase activity from Sepharose $6 B$}

Precipitated proteins from strain 3209 which redissolved during the second, third and fourth extractions with acetate buffer were concentrated, dialysed against $2 \mathrm{M}-\mathrm{NaCl}$ in acetate buffer and filtered through Sepharose 6B. Most of the mutansucrase activity eluted well after the void volume, immediately before dextransucrase activity (Fig. 1 a). Fructosyltransferase was eluted predominantly between the void volume and mutansucrase but some activity was also detected in subsequent tubes. Virtually no fructosyltransferase activity was lost during gel filtration and the specific enzymic activity of the most active fractions was increased 8-fold.

Fractions ( 29 to 33 ) with mutansucrase activity from the first column were pooled and dialysed for $72 \mathrm{~h}$ at $4{ }^{\circ} \mathrm{C}$ against four changes (each $4 \mathrm{l}$ ) of distilled water. Only $22 \%$ of the mutansucrase activity was retained during dialysis, but this loss was largely compensated by a $1280 \%$ increase in dextransucrase activity (Table 2 , line 8 ). The dialysate was concentrated, 
Table 2. Specific activities and yields of glucosyl- and fructosyltransferases after filtration through Sepharose $6 B$

Activities refer to the enzyme preparations from strain 3209 used for the experiments shown in Fig. 1.

\begin{tabular}{|c|c|c|c|}
\hline \multirow[b]{2}{*}{ Sample } & \multicolumn{3}{|c|}{$\begin{array}{l}\text { Enzyme activities } \\
\left.\text { [mg glucose or fructose polymerized } \mathrm{h}^{-1}(\mathrm{mg} \text { protein })^{-1}\right]\end{array}$} \\
\hline & Fructosyltransferase & Mutansucrase & Dextransucrase \\
\hline
\end{tabular}

Redissolved $\left(\mathrm{NH}_{4}\right)_{2} \mathrm{SO}_{4}$ precipitate applied to 1st Sepharose column

Dextransucrase pool (fractions 35 to 48 ) from 1st Sepharose column

Mutansucrase (fractions 29 to 33 ) from 1st Sepharose column

Mutansucrase applied to 2nd Sepharose column after dialysis

Fructosyltransferase pool (fractions 30 to 34 ) from 2nd Sepharose column

Leading edge of glucosyltransferase pool (fractions 39 to 44) from 2 nd Sepharose column

Trailing edge of glucosyltransferase pool (fractions 45 to 50) from 2 nd Sepharose column

\begin{tabular}{|c|c|c|}
\hline Fructosyltransferase & Mutansucrase & Dextransu \\
\hline 3.86 & $4 \cdot 39$ & $7 \cdot 67$ \\
\hline $1 \cdot 40$ & $0 \cdot 10$ & $12 \cdot 90$ \\
\hline $5 \cdot 11$ & $24 \cdot 5$ & $0 \cdot 84$ \\
\hline $4 \cdot 48$ & $5 \cdot 46$ & $10 \cdot 00$ \\
\hline $33 \cdot 2$ & 0.05 & 0.2 \\
\hline $2 \cdot 52$ & 0.05 & $35 \cdot 1$ \\
\hline $0 \cdot 70$ & $0 \cdot 05$ & $38 \cdot 3$ \\
\hline $\begin{array}{l}88 \% \\
89 \%\end{array}$ & $\begin{array}{r}22 \% \\
0 \%\end{array}$ & $\begin{array}{r}1283 \% \\
108 \%\end{array}$ \\
\hline
\end{tabular}

Activity retained during dialysis of pooled fractions

29 to 33 from 1st Sepharose column

Activity recovered from 2 nd Sepharose column

re-equilibrated with $2 \mathrm{M}-\mathrm{NaCl}$ in acetate buffer and again filtered through Sepharose 6B (Fig. $1 b$ ). No mutansucrase activity was detected in the eluate, but more dextransucrase activity was eluted than was applied to the column (Table 2 , line 9 ). When fractions with dextransucrase activity were incubated with sucrose in the presence of $1.55 \mathrm{M}-\left(\mathrm{NH}_{4}\right)_{2} \mathrm{SO}_{4}$, the glucan formed was predominantly insoluble in water. Carbohydrate was readily detected associated with the eluted enzyme, so it is possible that this carbohydrate interacted with the column matrix and that the elution of dextransucrase activity was thereby retarded.

Glucosyltransferase preparations from strain C67-1 differed from those from strain 3209 in that only a trace of mutansucrase activity was detected in the eluate from the first Sepharose 6B column. More dextransucrase activity was again eluted than was applied to the column but a mixture of water-insoluble and soluble glucans were formed when active fractions were incubated with sucrose in the presence of $1.55 \mathrm{M}-\left(\mathrm{NH}_{4}\right)_{2} \mathrm{SO}_{4}$.

\section{Polyacrylamide gel electrophoresis of glucosyl- and fructosyltransferases eluted from Sepharose 6B}

Proteins in the sample applied to the first Sepharose column and in the pools of eluted fructosyl- and glucosyltransferase activity (Fig. $1 b$ ) were separated by SDS-polyacrylamide gel electrophoresis. Although the sample applied to the first Sepharose column (Fig. 1a) was extremely heterogeneous (Fig. 2, track 1), essentially only three protein species of high molecular weight were detected in samples corresponding to the trailing edge of the peak of dextransucrase activity illustrated in Fig. $1(b)$ : the lowest molecular weight component of the triplet was the dominant species (Fig. 2, track 2). The leading edge of the dextransucrase peak was more heterogeneous and was relatively enriched with the highest molecular weight component of the triplet (Fig. 2, track 3). The fructosyltransferase pool was extremely heterogeneous, but the two most prominent protein bands were absent from the dextransucrase pools (Fig. 2, track 4). After electrophoresis, some gels were incubated with sucrose, Lubrol and dextran. White bands of polysaccharide appeared after 24 to $48 \mathrm{~h}$ at positions corresponding to the three high molecular weight proteins in the dextransucrase pool, 

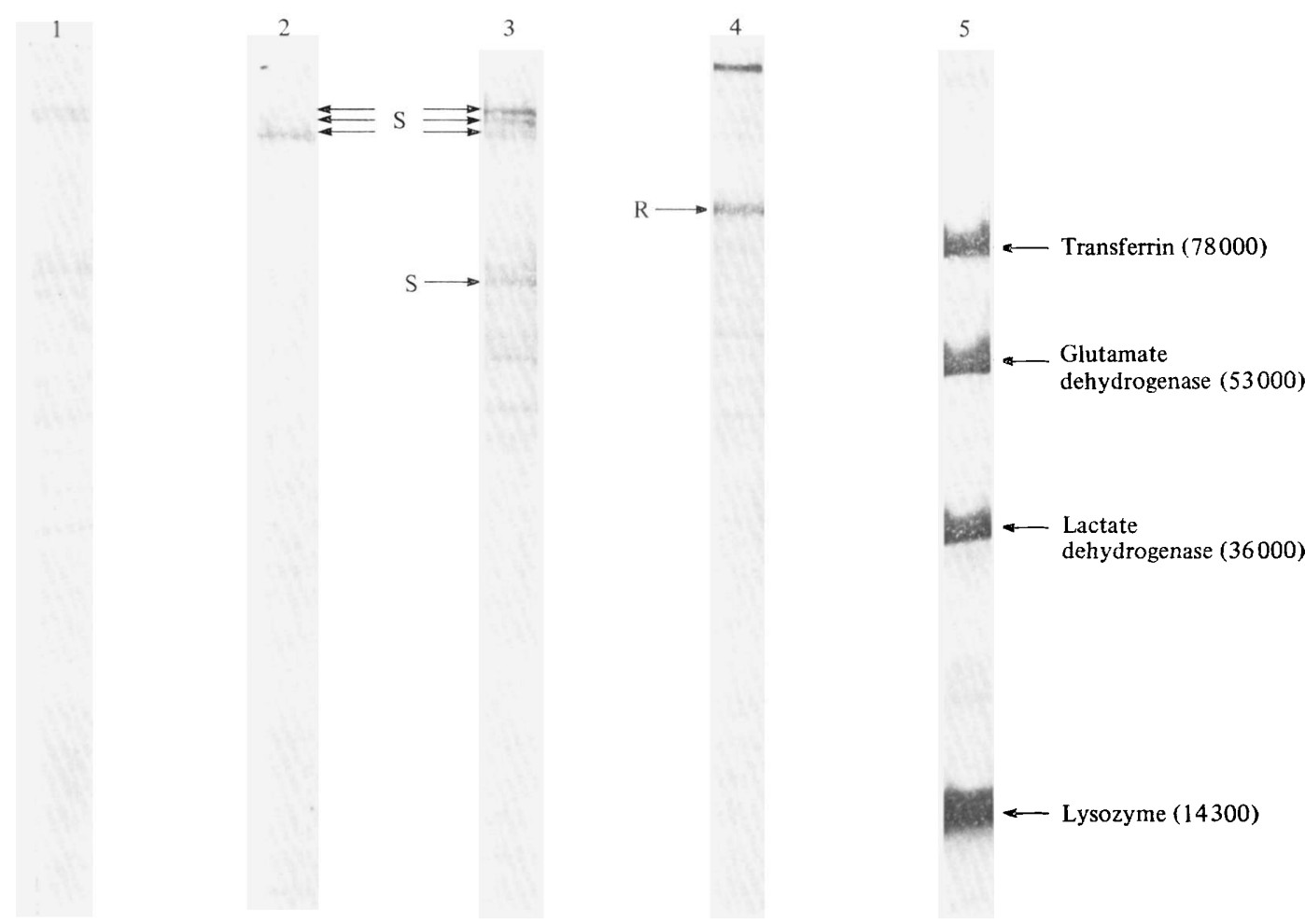

Fig. 2. SDS-polyacrylamide gel electrophoresis of glucosyl- and fructosyltransferase samples. Track 1: sample applied to the 1st Sepharose 6B column (Fig. 1a). Tracks 2 to 4 were loaded with samples eluted from the 2 nd Sepharose column (Fig. 1 b): track 2, glucosyltransferase fractions 44 to 50 ; track 3, glucosyltransferase fractions 39 to 43 ; track 4, fructosyltransferase fractions 30 to 33. Track 5: protein standards. $\mathrm{S}$ and $\mathrm{R}$ indicate where white bands of polymer formed when gels were incubated with sucrose $(\mathbf{S})$ or raffinose $(\mathbf{R})$.

and with some samples two or three bands of polymer formation were associated with proteins of lower molecular weight. When gels were incubated with raffinose [a substrate for fructosyl- but not for glucosyltransferase (Russell, 1979)], the only protein species to form polysaccharide rapidly was one of the dominant species in the fructosyltransferase pool (Fig. 2, track 4). After $48 \mathrm{~h}$, faint deposits of polysaccharide were also visible at positions corresponding to the three high molecular weight species in the dextransucrase pools. It is assumed, therefore, that the protein which readily becomes visible when incubated with raffinose is fructosyltransferase, and that the proteins which form polysaccharides from sucrose are predominantly glucosyltransferases. Although it is surprising that glucosyland fructosyltransferase activities had been retained by samples heated with SDS, similar phenomena were reported previously by Scales et al. (1975) and by Russell (1979). No residual activity was detected after electrophoresis if samples were heated for more than $5 \mathrm{~min}$, but the pattern of stained proteins was unchanged.

\section{Effect of enzyme concentration on soluble and insoluble glucan synthesis}

The loss of mutansucrase activity during dialysis and gel filtration and the differences in protein composition of the leading and trailing edges of the peak of dextransucrase activity were consistent with the possibility that both dextransucrase and another protein are required to catalyse insoluble glucan synthesis. Samples from column fractions were therefore recombined and assayed for insoluble polymer formation when incubated with 

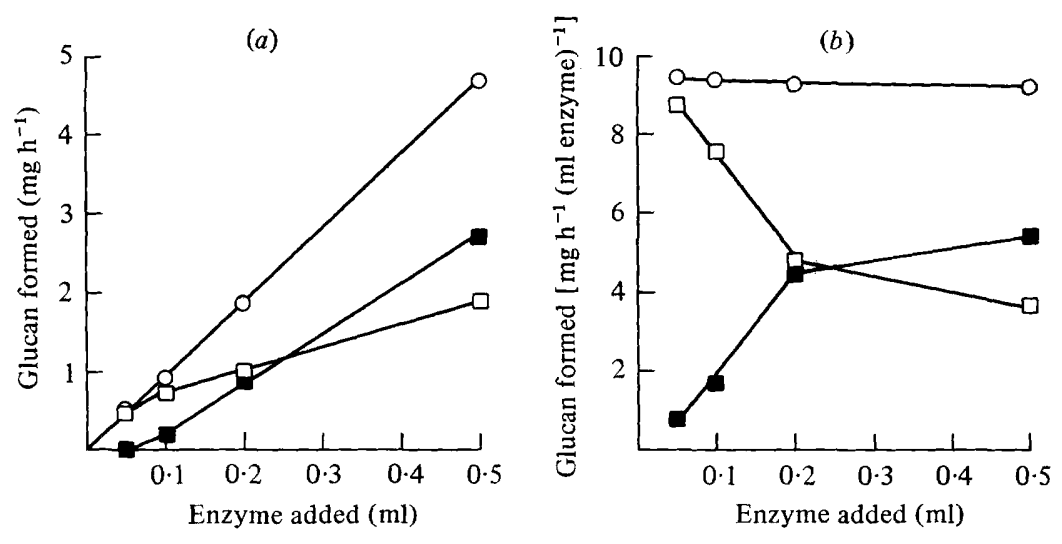

Fig. 3. Effect of enzyme concentration on the rates of synthesis of soluble ( $\square$ ), insoluble ( $\square$ ) and total $(\bigcirc)$ glucan in the presence of $1.55 \mathrm{M}-\left(\mathrm{NH}_{4}\right)_{2} \mathrm{SO}_{4}$. In $(a)$, rates are expressed as mg glucan formed in the assay tube $\mathrm{h}^{-1}$; in $(b)$, rates are expressed as mg glucan formed $\mathrm{h}^{-1}$ (ml enzyme $)^{-1}$. The enzyme used for this experiment was fraction 39 , Fig. $1(b)$.

sucrose and $\left(\mathrm{NH}_{4}\right)_{2} \mathrm{SO}_{4}$. Enzyme $(0.1 \mathrm{ml})$ from fractions 39 and 47 (Fig. $1 b$ ) formed 0 and $75 \mu \mathrm{g}$ insoluble glucan $\mathrm{h}^{-1}$ and 51 and $16 \mu \mathrm{g}$ soluble glucan $\mathrm{h}^{-1}$ when incubated with sucrose alone; in contrast, $170 \mu \mathrm{g}$ insoluble glucan $\mathrm{h}^{-1}$ and only $34 \mu \mathrm{g}$ soluble glucan $\mathrm{h}^{-1}$ were formed when $0.1 \mathrm{ml}$ samples of these fractions were incubated together. Thus insoluble glucan synthesis was apparently stimulated $2 \cdot 3$-fold but soluble glucan synthesis was inhibited 2-fold. Similar results were obtained with three independent enzyme samples from strain 3209 and with glucosyltransferase from strain C67-1. However, stimulations of the same order of magnitude were also obtained when samples of enzyme from adjacent fractions were combined. This suggests that the stimulatory effects were due to a nonlinear dependence of the rate of insoluble glucan synthesis on the enzyme concentration rather than to fractions such as 39 and 47 (Fig. 1 b) being relatively enriched in different proteins required for mutan synthesis. This was confirmed in subsequent experiments designed to determine the optimal conditions for insoluble glucan synthesis by partially purified dextransucrase.

At the lowest enzyme concentrations only soluble glucan was formed even in the presence of $1.55 \mathrm{M}$ - $\left(\mathrm{NH}_{4}\right)_{2} \mathrm{SO}_{4}$, but with higher concentrations most of the product was waterinsoluble (Fig. $3 a$ ). When the data were expressed as specific activities, it became apparent that the sum of the rates of soluble and insoluble glucan synthesis was constant, but that as the enzyme concentration was increased, insoluble glucan was progressively formed instead of soluble glucan (Fig. $3 b$ ).

\section{Effect of the concentration of ammonium sulphate and other salts on soluble and insoluble glucan synthesis}

The rate of insoluble glucan synthesis in the presence of various concentrations of $\left(\mathrm{NH}_{4}\right)_{2} \mathrm{SO}_{4}$ was determined. The optimal concentration was $1.55 \mathrm{M}$; at higher concentrations insoluble glucan synthesis was inhibited. Ammonium citrate also stimulated insoluble glucan synthesis, the optimum concentration being $1 \mathrm{M}$. No insoluble glucan was formed when partially purified dextransucrase was incubated with sucrose and $1.0,2.0$ or $3 \cdot 0 \mathrm{M}$ $\mathrm{Na}_{2} \mathrm{SO}_{4}, \mathrm{NaCl}$ or $\mathrm{KCl}$ or with $0.6 \mathrm{M}-\mathrm{K}_{2} \mathrm{SO}_{4}$. 


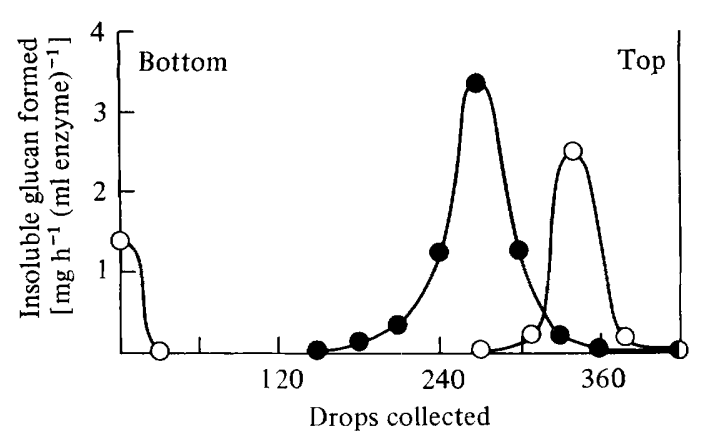

Fig. 4. Sedimentation of partially purified glucosyltransferase through a glycerol density gradient in the presence or absence of $1.55 \mathrm{M}-\left(\mathrm{NH}_{4}\right)_{2} \mathrm{SO}_{4}$. Glucosyltransferase from strain $\mathrm{C} 67-1$ was filtered through Sepharose $6 \mathrm{~B}$, concentrated by dialysis against polyethylene glycol and then against acetate buffer at $4{ }^{\circ} \mathrm{C}$. Samples $(0 \cdot 3 \mathrm{ml})$ mixed with marker proteins were loaded on to $12.6 \mathrm{ml}$ linear 10 to $30 \%(\mathrm{v} / \mathrm{v})$ glycerol gradients with $(\mathrm{O})$ or without (O) $1.55 \mathrm{M}-\left(\mathrm{NH}_{4}\right)_{2} \mathrm{SO}_{4}$. Tubes were centrifuged and fractionated as described in Methods. The glucosyltransferase activity of each $0.8 \mathrm{ml}$ fraction was assayed by incubating $0.25 \mathrm{ml}$ with $2.25 \mathrm{ml}$ sucrose, $1.55 \mathrm{M}-\left(\mathrm{NH}_{4}\right)_{2} \mathrm{SO}_{3}$ and acetate buffer for $6.5 \mathrm{~h}$ at $37^{\circ} \mathrm{C}$.

\section{Apparent molecular weight of glucosyltransferase during glycerol gradient centrifugation}

In the absence of $\left(\mathrm{NH}_{4}\right)_{2} \mathrm{SO}_{4}$, glucosyltransferase sedimented through a linear glycerol gradient as a symmetrical peak of activity with an apparent molecular weight in the range 100000 to 110000 (Fig. 4). Most of the activity sedimented slightly less rapidly in the presence of $1.55 \mathrm{M}-\left(\mathrm{NH}_{4}\right)_{2} \mathrm{SO}_{4}$, but $30 \%$ was recovered as a pellet at the bottom of the tube (Fig. 4). Thus, part of the sample applied to the gradient had been aggregated (or precipitated) by $1.55 \mathrm{M}-\left(\mathrm{NH}_{4}\right)_{2} \mathrm{SO}_{4}$. Each active fraction catalysed the synthesis of only soluble glucan when incubated with sucrose alone but predominantly formed insoluble glucans when incubated with sucrose and $1.55 \mathrm{M}-\left(\mathrm{NH}_{4}\right)_{2} \mathrm{SO}_{4}$. Graphs of the two types of activity plotted against fraction number gave coincident peaks.

\section{Effect of dextran on rates of soluble and insoluble glucan synthesis}

One major source of confusion in the glucosyltransferase literature concerns the effect of dextran on glucan synthesis (compare Germaine et al., 1977, with Robyt \& Corrigan, 1977). In general, dextran stimulates the rate of soluble glucan synthesis, but inhibits insoluble glucan synthesis (Montville et al., 1977).

Even very low concentrations of dextran apparently inhibited the rate of formation of insoluble glucan by the supernatant fluid from cultures of strain C67-1, but soluble glucan synthesis was stimulated (Fig. 5). In several, but not all, experiments, the increased rate of soluble glucan synthesis was greater than the inhibition of insoluble glucan synthesis, so the total glucosyltransferase activity increased when dextran was added. Essentially similar results were obtained with unpurified enzyme from strain 3209, but the concentrations of dextran used were far below those used by Germaine et al. (1974) to stimulate dextran synthesis by glucosyltransferase from the serotype $d$ strain, 6715 .

Dextran slightly stimulated the total rate of glucan synthesis by partially purified glucosyltransferase from strain 3209 in the absence of $\left(\mathrm{NH}_{4}\right)_{2} \mathrm{SO}_{4}$, but the product was entirely water-soluble. Although the total amount of glucan formed was unaffected by $\left(\mathrm{NH}_{4}\right)_{2} \mathrm{SO}_{4}$, the relative proportions of soluble and insoluble products depended on both the incubation period and the presence of dextran (compare Figs $6 a$ and $6 b$ ). In the absence of dextran the initial product was entirely water-soluble, but after $0.4 \mathrm{~h}$ almost all of the glucan formed was insoluble (Fig. 6a). When dextran was added, insoluble glucan was synthesized only after a lag of $1.5 \mathrm{~h}$ and the appearance of the first insoluble product coincided with a 


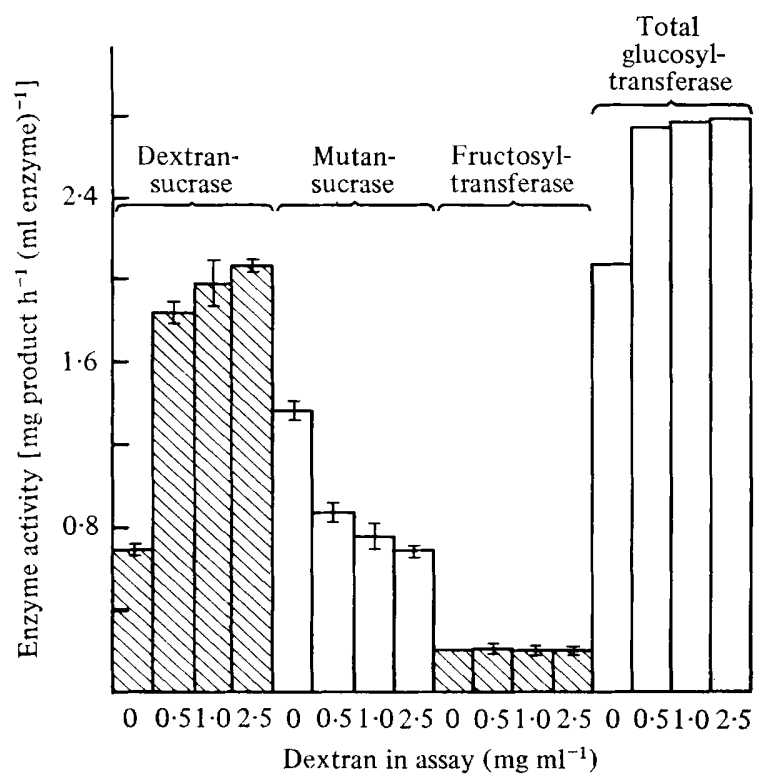

Fig. 5. Effect of dextran on glucosyl- and fructosyltransferase activities. Strain C67-1 was grown in continuous culture with excess glucose. Culture supernatant $(1.0 \mathrm{ml})$ was incubated for $2 \mathrm{~h}$ at $37^{\circ} \mathrm{C}$ with $1.0 \mathrm{ml} 0.29 \mathrm{M}$-sucrose and various concentrations of dextran (mol. wt 60000 to 90000 ), and the quantities of accumulated glucan and fructan were determined. The error bars indicate the range of enzyme activities calculated from two independent assays.

decrease in the concentration of soluble glucan (Fig. $6 b$ ). The subsequent rate of insoluble product formation was sufficiently greater when dextran was added to compensate for the loss of water-soluble product (Fig. $6 b$ ). These results are entirely consistent with the suggestion that glucosyltransferase first forms a water-soluble precursor (a 'dextran') which is subsequently converted into the insoluble glucan (Germaine et al., 1977).

\section{Ammonium sulphate-dependent synthesis of insoluble glucan by glucosyltransferase from a non-cariogenic mutant}

Mutant C67-25, derived from strain C67-1, differs from its parent in that it is unable to induce carious lesions when experimental animals are fed a sucrose-rich diet (de Stoppelaar et al., 1971; Wenham, 1979). During growth in continuous culture, the mutant secretes approximately $40 \%$ of the glucosyltransferase activity of its parent, but the glucan product is entirely water-soluble (Wenham et al., 1978). Enzyme from 41 of culture supernatant was precipitated with $70 \%$ saturated $\left(\mathrm{NH}_{4}\right)_{2} \mathrm{SO}_{4}$, redissolved in acetate buffer, equilibrated with $2 \mathrm{M}-\mathrm{NaCl}$ in acetate buffer and filtered through a column of Sepharose 6B. A single peak of glucosyltransferase activity was eluted well after the void volume. When incubated with sucrose alone, active fractions catalysed the synthesis of only soluble glucans, but both soluble and insoluble glucans were formed during incubation with sucrose plus $1.55 \mathrm{M}$ $\left(\mathrm{NH}_{4}\right)_{2} \mathrm{SO}_{4}$. Thus, even glucosyltransferase from a non-cariogenic mutant strain will catalyse insoluble glucan synthesis under these incubation conditions.

\section{Susceptibility of glucans to hydrolysis by dextranase and mutanase}

The soluble glucans synthesized by partially purified glucosyltransferases from $S$. mutans strains 3209, C67-1 and $\mathrm{C} 67-25$ in the absence of $\left(\mathrm{NH}_{4}\right)_{2} \mathrm{SO}_{4}$ were resistant to hydrolysis by mutanase but were degraded by dextranase (Table 3 ). In contrast, the insoluble glucans made with samples of the same enzyme preparations in the presence of $1.55 \mathrm{M}-\left(\mathrm{NH}_{4}\right)_{2} \mathrm{SO}_{4}$ 


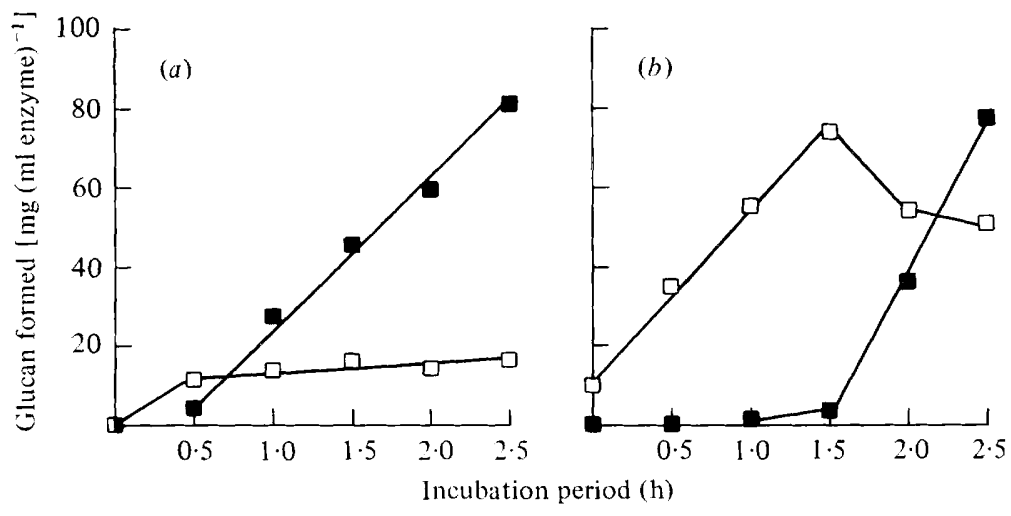

Fig. 6. Effect of dextran on the time course of soluble ( $\square)$ and insoluble $(\boldsymbol{\square})$ glucan synthesis. The partially purified dextransucrase from strain $3209(0 \cdot 1 \mathrm{ml}$ of fraction 48 , Fig. $1 b)$ was incubated with $0.5 \mathrm{ml} 0.29 \mathrm{M}$-sucrose and $0.1 \mathrm{M}$-sodium acetate, $\mathrm{pH} 6.0$ (final vol. $2.0 \mathrm{ml}$ ) without $(a)$ or with (b) $60 \mu \mathrm{g}$ dextran $\mathrm{ml}^{-1}$.

\section{Table 3. Hydrolysis of glucans by mutanase and dextranase}

Polymers were incubated for $2 \mathrm{~h}$ at $37^{\circ} \mathrm{C}$ with dextranase or mutanase $\left(1 \mathrm{mg} \mathrm{ml}{ }^{-1}\right)$. The concentration of reducing sugar after incubation was corrected for the concentration of reducing sugar in control tubes with enzyme alone and with glucan alone and was then expressed as a percentage of the total concentration of glucose equivalents originally added.

\begin{tabular}{|c|c|c|c|c|}
\hline \multirow[b]{2}{*}{ Glucan } & \multirow{2}{*}{$\begin{array}{l}\text { Glucan } \\
\text { concn } \\
\left(\mathrm{mg} \mathrm{ml}^{-1}\right)\end{array}$} & \multirow{2}{*}{$\begin{array}{l}\text { Strain of } \\
\text { S. mutans }\end{array}$} & \multicolumn{2}{|c|}{ Percentage hydrolysed by } \\
\hline & & & Mutanase & Dextranase \\
\hline $\begin{array}{l}\text { glucan } \\
\text { glucan } \\
\text { thesized by partially } \\
\text { transferase }\end{array}$ & $\begin{array}{l}1 \cdot 0 \\
1 \cdot 0 \\
0 \cdot 84\end{array}$ & $\begin{array}{l}\overline{-} \\
3209 \\
\text { C67-1 } \\
\text { C67-25 }\end{array}$ & $\begin{array}{r}35 \\
3 \\
2 \\
0 \\
3\end{array}$ & $\begin{array}{r}4 \\
37 \\
20 \\
17 \\
23\end{array}$ \\
\hline $\begin{array}{l}\text { nthesized by partially } \\
\text { transferase in the presence } \\
\mathrm{SO}_{4}\end{array}$ & $0 \cdot 73$ & $\begin{array}{l}3209 \\
\text { C67-1 } \\
\text { C67-25 }\end{array}$ & $\begin{array}{l}14 \\
31 \\
18\end{array}$ & $\begin{array}{l}13 \\
12 \\
13\end{array}$ \\
\hline by the culture filtrate & $1 \cdot 17$ & $\begin{array}{l}3209 \\
\text { C67-1 }\end{array}$ & $\begin{array}{l}21 \\
23\end{array}$ & $\begin{array}{l}6 \\
6\end{array}$ \\
\hline
\end{tabular}

were hydrolysed by both mutanase and dextranase. As expected, mutans synthesized by culture filtrates of strains 3209 and $\mathrm{C} 67-1$ in the absence of $1.55 \mathrm{M}-\left(\mathrm{NH}_{4}\right)_{2} \mathrm{SO}_{4}$ were far more extensively hydrolysed by mutanase than by dextranase.

Commercial dextran with predominantly $(1 \rightarrow 6)-\alpha$ glycosidic bonds was extensively hydrolysed by dextranase but was a poor substrate for mutanase (Table 3 ). Conversely, the $(1 \rightarrow 3)$ - $\alpha$-glucan from Peptobovus betulinus was extensively hydrolysed by mutanase but not by dextranase. We can conclude, therefore, that the insoluble glucans made by dextransucrase in the presence of $1.55 \mathrm{M}-\left(\mathrm{NH}_{4}\right)_{2} \mathrm{SO}_{4}$ are structurally different to the soluble glucans made by the same enzyme: full structural analyses of these polymers will be required to confirm that they contain a high proportion of $(1 \rightarrow 3)-\alpha$ bonds which are absent from the soluble product of the dextransucrase reaction. 


\section{DISCUSSION}

Results of previous experiments in this laboratory led to the suggestion that dextransucrase and mutansucrase activities result from interconvertible forms of a single glucosyltransferase protein (Mohan et al., 1979). Ebert \& Schenk (1968) also proposed that soluble and insoluble glucans were synthesized by a single enzyme and a plausible mechanism was subsequently proposed by Robyt (1979).

Our results provide an experimental basis for Robyt's model and confirm that glucosyltransferase occurs in two forms which differ in their degree of aggregation. Evidence that the aggregated form catalyses insoluble glucan synthesis includes the retention of mutansucrase activity in proteins which failed to redissolve after precipitation by $70 \%$ saturated $\left(\mathrm{NH}_{4}\right)_{2} \mathrm{SO}_{4}$ (Table 1) and the elution of mutansucrase before dextransucrase from Sepharose 6B (Fig. 1 $a$, Table 2). In contrast, dextransucrase activity redissolved more readily after precipitation with $\left(\mathrm{NH}_{4}\right)_{2} \mathrm{SO}_{4}$ (Table 1), eluted from Sepharose 6B after mutansucrase activity and sedimented slowly through a glycerol density gradient, with an apparent molecular weight in the range 100000 to 110000 (Fig. 4).

The total glucosyltransferase activity (i.e. the sum of the dextransucrase and mutansucrase activities) was almost quantitatively recovered after dialysis and gel filtration through two columns of Sepharose 6B, but mutansucrase was gradually lost and there was a corresponding increase in dextransucrase activity (Table 1, Fig. $1 b$ ). This demonstrates that dextransucrase activity can be released from a mutansucrase aggregate. Conversely, dextransucrase preparations which were devoid of mutansucrase activity catalysed the synthesis of insoluble glucan when incubated with sucrose and $1.55 \mathrm{M}-\left(\mathrm{NH}_{4}\right)_{2} \mathrm{SO}_{4}$ and were partially reaggregated to a form that sedimented rapidly through a glycerol density gradient (Table 1, Fig. 4). Most of the dextransucrase activity sedimented less rapidly in the presence of $1.55 \mathrm{M}-\left(\mathrm{NH}_{4}\right)_{2} \mathrm{SO}_{4}$ because this high concentration of salt increases the density of the gradient; glycerol partially inhibits glucan synthesis, so we assume that this interaction prevented the complete aggregation of dextransucrase. The concentrated dextransucrase applied to electrophoresis gels migrated slowly and catalysed insoluble glucan synthesis on incubation with sucrose after electrophoresis (Fig. 2). These observations and the enzyme concentration dependence of soluble and insoluble glucan synthesis (Fig. 3) provide further evidence that the disaggregated dextransucrase can be converted back to an aggregated form which catalyses mutan synthesis. Until dextransucrase has been purified to homogeneity, it will be impossible to state whether other proteins or a polysaccharide are also required for the disaggregated enzyme to catalyse mutan synthesis, or for the aggregation process itself. Mutant C67-25 could be non-cariogenic because its glucosyltransferase is unable to aggregate naturally to the form which catalyses mutan synthesis, the molecular defect being in either the primary structure of glucosyltransferase itself, or in the hypothetical association factor.

One possible explanation of the effect of dextran is that it preferentially binds to disaggregated glucosyltransferase. If so, disaggregation would be promoted either because dextran increases the solubility of the disaggregated form, or because it competes with other glucosyltransferase molecules or association factors for binding sites. This suggestion is similar to that of Montville et al. (1977): it implies that dextran inhibits the rate of $(1 \rightarrow 3)-\alpha$ bond formation. Alternatively, dextran could simply compete with precursors of insoluble glucans as substrates into which new $(1 \rightarrow 3)-\alpha$ bonds are inserted. Dextrans are extremely soluble in water: a considerable number of $(1 \rightarrow 3)-\alpha$ branch points would therefore need to be incorporated before an exogenous dextran precursor became insoluble and therefore detectable in the mutan assay. This second explanation, which is more consistent with observations in Fig. $6(a, b)$, predicts that dextran would have no effect on the rate of $(1 \rightarrow 3)-\alpha$ bond formation, that it would delay the first appearance of insoluble glucan during incubation with sucrose, but that after this delay, the subsequent rate of mutan accumulation would 
be enhanced as the precursor glucans were enlarged to their solubility limit. The second explanation is also consistent with reports that the magnitude of the dextran effects are independent of the molecular weight of the added primer, and are observed even when the terminal, non-reducing hydroxyl groups of the dextran have been blocked with tripsyl chloride (Germaine \& Schachtele, 1976; Robyt \& Corrigan, 1977).

Our model is also compatible with the mechanism for glucan synthesis proposed by Robyt (1979), namely that there are two equivalent nucleophilic sites on glucosyltransferase at which either sucrose or a polysaccharide can be bound. When preformed glucan is unavailable, glucosyltransferase binds sucrose at both sites with the release of fructose and formation of a $(1 \rightarrow 6)-\alpha$ bond by an insertion mechanism at C-1. A third sucrose molecule can then bind to the vacated site, fructose is again released and the glucosyl moiety is the acceptor in the formation of a second $(1 \rightarrow 6)-\alpha$ glycosidic bond. Robyt (1979) proposed that the same protein can catalyse $(1 \rightarrow 3)-\alpha$ bond formation when a preformed glucan is the glucosyl- or dextranosyl-acceptor in the absence of sucrose. If exogenous glucan must bind to one of the active sites before a $(1 \rightarrow 3)-\alpha$ bond is formed, enzyme aggregation will both decrease the accessibility of the second site to sucrose and will also increase the chance of dextranosyl-transfer between different enzyme molecules. Either effect would result in an increased rate of $(1 \rightarrow 3)-\alpha$ bond formation but a decreased rate of $(1 \rightarrow 6)-\alpha$ bond formation by the aggregated enzyme. We suggest that glucosyltransferase aggregation is an important factor in determining the rate of mutan synthesis by, and therefore the cariogenicity of, $S$. mutans strains.

We are grateful to Dr R. R. B. Russell for many helpful suggestions, for confirming the identity of the extracellular enzymes secreted by $S$. mutans and for communicating his results to us prior to publication. The research was supported by grants from The Medical Research Council to B.M.N. and J.A.C.

\section{REFERENCES}

Baird, J. K., Longyear, V. M. C. \& Ellwood, D. C. (1973). Insoluble and soluble glucans produced by extracellular glucosyltransferases from Streptococcus mutans. Microbios 8, 143-150.

Cole, J. A. (1977). A biochemical approach to the control of dental caries. Biochemical Society Transactions 5, 1232-1239.

Coleman, K. J., Cornish-Bowden, A. \& Cole, J. A. (1978). Purification and properties of nitrite reductase from Escherichia coli K12. Biochemical Journal 175, 483-493.

Dubois, M., Gilles, K. A., Hamilton, J. K., Rebers, P. A. \& Smith, F. (1956). Colorimetric method for the determination of sugars and related substances. Analytical Chemistry $\mathbf{2 8}$, 350-356.

Erert, K. H. \& SCHenK, G. (1968). Mechanisms of biopolymer growth: the formation of dextran and levan. Advances in Enzymology 30, 179-221.

Ebisu, S., Misaki, A., Kato, K. \& Kotani, S. (1974). The structure of water-insoluble glucans of cariogenic Streptococcus mutans formed in the absence and presence of dextranase. Carbohydrate Research 38, 374-381.

Ellwood, D. C., Baird, J. K., Hunter, J. R. \& LONGYEAR, V. M. C. (1976). Variations in surface polymers of Streptococcus mutans. Journal of Dental Research 55, C42-C49.
Fukui, K., Fukui, Y. \& Moriyama, T. (1974). Purification and properties of dextransucrase and invertase from Streptococcus mutans. Journal of Bacteriology 118, 796-804.

Germaine, G. R. \& Schachtele, C. F. (1976). Streptococcus mutans dextransucrase: mode of interaction with high molecular weight dextran and role in cellular aggregation. Infection and Immunity 13, 365-372.

Germaine, G. R., Chludzinski, A. M. \& SchachTELE, C. F. (1974). Streptococcus mutans dextransucrase: requirement for primer dextran. Journal of Bacteriology 120, 287-294.

Germaine, G. R., Harlander, S. K., Leung, W. L. S. \& Schachtele, C. F. (1977). Streptococcus mutans dextransucrase: functioning of primer dextran and endogenous dextranase in water-soluble and water-insoluble glucan synthesis. Infection and Immunity 16, 637-648.

GibBons, R. J. \& NYGAaRd, M. (1968). Synthesis of insoluble dextran and its significance in the formation of gelatinous deposits by plaque-forming streptococci. Archives of Oral Biology 13, 12491262.

Guggenheim, B. \& Newbrun, E. (1969). Extracellular glucosyltransferase activity of an HS strain of Streptococcus mutans. Helvetica odontologica acta 13, 84-97. 
Hodge, J. E. \& Hofreiter, B. T. (1962). Determination of reducing sugars in carbohydrates. Methods in Carbohydrate Chemistry 1, 386-388.

KoGA, T. \& INOUE, M. (1978). Cellular adherence, glucosyltransferase adsorption and glucan synthesis of Streptococcus mutans AHT mutants. Infection and Immunity 19, 402-410.

Kuramitsu, H. K. (1975). Characterization of extracellular glucosyltransferase activity of Streptococcus mutans. Infection and Immunity 12, 738749.

LAemmLI, U. K. (1970). Cleavage of structural proteins during the assembly of the head of bacteriophage T4. Nature, London 227, 680-689.

Lewicki, W. J., Long, L. W. \& Edwards, J. R. (1971). Determination of the structure of a broth dextran produced by a cariogenic Streptococcus. Carbohydrate Research 17, 175-182.

MCCABE, M. M. \& SмiтH, E. E. (1973). Origin of the cell-associated dextransucrase of Streptococcus mutans. Infection and Immunity 7, 829-838.

Mohan, S. B., Newman, B. M. \& Cole, J. A. (1979). The interconversion of dextransucrase and mutansucrase activities from cariogenic strains of Streptococcus mutans. FEMS Microbiology Letters 5, 69-72.

Montville, T. J., Cooney, C. L. \& Sinskey, A. J. (1977). Distribution of dextransucrase in Streptococcus mutans and observations on the effect of soluble dextran on dextransucrase activities. Infection and Immunity 18, 629-635.

RoBYT, J. F. (1979). Mechanisms involved in the biosynthesis of polysaccharides. Trends in Biochemical Sciences 4, 47-49.

Robyt, J. F. \& Corrigan, A. J. (1977). The mechanism of dextransucrase action: activation of dextransucrase from Streptococcus mutans $\mathrm{OMZ}$ 176 by dextran and modified dextran and the non-existence of the primer requirement for the synthesis of dextran. Archives of Biochemistry and Biophysics 183, 726-731.

RusselL, R. R. B. (1979). Use of Triton X-100 to overcome the inhibition of fructosyltransferase by SDS. Analytical Biochemistry 97, 173-175.

Scales, W. R., Long, L. W. \& Edwards, J. R. (1975). Purification and characterisation of a glucosyltransferase complex from the culture broth of Streptococcus mutans FA1. Carbohydrate Research 42, 325-338.

Schachtele, C. F., Harlander, S. K. \& Germaine, G. R. (1976). Streptococcus mutans dextransucrase: availability of disaggregated enzyme after growth in a chemically defined medium. Infection and Immunity 13, 1522-1524.

SHERP, H. W. (1971). Dental caries: prospects for prevention. Science 173, 1199-1205.

De Stoppelaar, J. D., van Houte, J. \& DE Moor, C. E. (1968). The presence of dextran-forming bacteria, resembling Streptococcus bovis and Streptococcus sanguis, in human dental plaque. Archives of Oral Biology 12, 1199-1201.

de Stoppelaar, J. D., Konig, K. G., Plasschaert, A. J. M. \& VAN DeR Hoeven, J. S. (1971). Decreased cariogenicity of a mutant of Streptococcus mutans. Archives of Oral Biology 16, 971-975.

WenHaM, D. G. (1979). The regulation of glucosyltransferase synthesis by Streptococcus mutans. Ph.D. thesis, University of Birmingham.

Wenham, D. G., Hennessey, T. D. \& Cole, J. A. (1978). Regulation of glucosyl- and fructosyltransferase synthesis by cariogenic strains of Streptococcus mutans. Proceedings of the Society for General Microbiology 5, 56.

Wenham, D. G., Hennessey, T. D. \& Cole, J. A. (1979). Regulation of glucosyl- and fructosyltransferase synthesis by continuous cultures of Streptococcus mutans. Journal of General Microbiology 114, 117-124. 